\title{
Selected Reference Books of 1968-69
}

\section{INTRODUCTION}

$\mathrm{T}$ HIS ARTICLE continues the semiannual series $^{1}$ originally edited by Constance M. Winchell. Although it appears under a byline, the list is actually a project of the Reference Department of the Columbia University Libraries, and notes are signed with the initials of the individual staff members. ${ }^{2}$

Since the purpose of the list is to present a selection of recent scholarly and foreign works of interest to reference workers in university libraries, it does not pretend to be either well balanced or comprehensive. Code numbers (such as AA71, 1EA29) have been used to refer to titles in the Guide to Reference Books $s^{3}$ and its Supplement.

\section{BIBLIOGRAPHY}

Gray, Richard A., comp. Serial Bibliographies in the Humanities and Social Sciences. Ann Arbor, Mich.: Pierian Pr., 1969. 345p. \$7.00. (68-58895).

Proposing to "identify and designate the salient characteristics" (Introduction) of serially published bibliographies of primary utility to humanists and social scientists, this volume cites both currently published and defunct works, those complete in themselves, and those that appear as features within other serials. Special attention has been paid to useful but little known lists.

Arrangement is classified by Dewey numbers; entries contain title, with trans-

\footnotetext{
${ }^{1} C R L$, January and July issues starting January, 1952.

${ }^{2}$ Linda Benson, Rita Keckeissen, Georgia Lanzano, Eileen McIlvaine, Mary Ann Miller, Heidimarie Peterson, Janet Schneider, Nancy Schroeder.

${ }^{3}$ Constance M. Winchell, Guide to Reference Books (8th ed.; Chicago: American Library Association, 1967 ); Supplement (Chicago: ALA, 1968).
}

lation if not in English; starting date for current, and inclusive dates for noncurrent, publications; full imprint for separately published series, and journal title for "hidden" bibliographies. Descriptive annotation is given by means of a number and letter code described in the introduction and given in chart form on the endpapers. This permits much information on language, form of materials included, frequency, bibliographic arrangement, and contents to be neatly compressed into a single line, but requires reference to the code for explanation. There are four indexes to aid in reference use.-R.K.

\section{Archives}

Brooks, Philip C. Research in Archives; the Use of Unpublished Primary Sources. Chicago: University of Chicago Pr., [1969]. 127p. \$5.75. (69-19273).

This manual is addressed to the researcher or the graduate student who lacks instruction in the use of unpublished sources. Seven short chapters deal with problems involved in finding and using archival materials, together with such questions as choosing a topic and organizing the search; responsibility of the archivist and the researcher; limitations of access; notes and copies; the critical attitude toward sources; and modern techniques of reproduction. There is a short bibliography and an index.-R.K.

\section{ENCYCLOPEDIAS}

Encyclopaedia Universalis. Paris: Encyclopaedia Universalis France, 1968v.1- . (In progress) ill. (2700F).

\section{Contents: v.1-3, Aalto-Causalité.}

The product of a joint effort of the Encyclopaedia Britannica and the Club Français du Livre, this new French-language general encyclopedia is intended both for 
reference and for in-depth informative reading. Sixteen of its twenty volumes will constitute the text; three will form the thesaurus or index; and one will act as the organum or summary and systematic guide.

Because its intention is predominantly systematic, entries are limited to broad articles. Understandably, little emphasis has been placed on biography. Many crossreferences are provided in the text from specific headings which have no separate entries to the broad heading which has been adopted. Even so, the encyclopedia will be limited in its usefulness until the index volumes appear, for such headings as "Anglais (Art)" and "Anglais (Droit)" have been used. The arrangement, despite the emphasis on subject correlation, is alphabetical.

The format is quite agreeable, illustrations numerous and attractive. With the exception of the rare short entry, each article is preceded by a table which presents the headings used within the article to organize the material. An overview of the subject follows, outlining its importance and problems. At the end of the treatment of a subject over which there is some controversy a section of "débats ouverts" presents opposing viewpoints. Bibliographies emphasizing standard and recent French works are appended to the articles; articles are signed with initials. References to related headings appear at the end of each article.-L.B.

\section{Periodicals and Newspapers}

Committee on Latin America. Latin American Economic and Social Serials. London: C. Bingley; [Hamden, Conn.], Archon Books, 1969. 189p. \$7.00. (74-382598).

This union list of current and recent Latin American economic and social science serials held in British libraries was published as part of an effort to promote interest in Latin American studies in the United Kingdom. Latin America has been interpreted as including the islands in the Caribbean as well as Central and South America; "economic" has been broadly interpreted to include agricultural serials when the important products of an area are considered therein. Publications known to have ceased prior to 1945 have been excluded. Arrangement is by title within geographical area; general sections for Latin America and the Caribbean list serials published by international organizations or those of a general nature published outside Latin America. An index of sponsoring bodies and an index of titles are useful additions. Items which are indexed in the Index to Latin American Periodicals (Guide AF154) have been so designated.-J.S.

\section{Latin American Newspapers in United} States Libraries; a Union List. Compiled . . . by Steven M. Charno. Austin: Univ. of Texas Pr., [1969]. 619p. \$20.00. (Conference on Latin American History, Publ. 2) (69-63004).

Compiled and edited in the Serial Division of the Library of Congress for the Conference on Latin American History, this union list represents an initial step toward increased utilization of this source material. The more than 5,500 titles in seventy reporting libraries include publications of twenty Latin American republics and Puerto Rico. Objective of the inventory "has been not only the traditional provision of a key to the researcher, in need of specific material, but also . . . because of the physical deterioration of the pulp newspaper files, the identification of the holdings of specific titles so that a composite of such holdings could be merged in the preparation of master negative microfilms."-Introduction. Although specialized periodicals are excluded, official gazettes before 1900 have been listed because of their general news value. Arrangement is by place of publication, first by country then by city, without index approach. Each entry consists of title, frequency, and beginning date when available. Additional notes concerning title and frequency changes, suspensions, and similar information are given wherever possible.-J.S.

Kujoth, Jean Spealman. Subject Guide to Periodical Indexes and Review Indexes. Metuchen, N.J.: Scarecrow Pr., 1969. 129p. \$5.00. (79-1268).

Using a subject classification roughly 
corresponding to major-subject departments in colleges and universities, the "academic-subject index" of this guide can lead the librarian or student quickly and easily to lists of indexing sources in various fields. Code letters follow each title, and by referring to the "type-of-information code" the user can learn what kinds of articles or types of reviews these specific works index. In the "title descriptions" section is found a full annotation, including the form, content, and subject coverage of each title cited in the "academic-subject index." Finally, a list of the sources which perform the particular functions enumerated in the "type-of-information code" (e.g., indexing of primarily general or popular material; indexing of reviews of tape recordings) can be seen at a glance by referring to the "summary of titles" which is presented in tabular form. This is a concise guide, well organized for easy use.-M.M.

\section{Dissertations}

West, Earle H. A Bibliography of Doctoral Research on the Negro, 19331966. [Ann Arbor, Mich.], Xerox, University Microfilms, 1969 . 134p. $\$ 5.00$. (7376349).

The compiler has drawn from American Doctoral Dissertations and Dissertation Abstracts (both of which are now University Microfilms publications) citations to some 1,500 dissertations "covering every aspect of study relating to the Negro and the United States ... or dealing primarily with the problem of race." -Introduction. Arrangement is topical, with fairly general headings such as "Religion," "Rural Problems," "The Courts and Law." The author index gives volume and page reference to Dissertation Abstracts, together with order information for those dissertations available for purchase from University Microfilms. This will be a useful list, and it is somewhat surprising to see which topics have received most attention in doctoral research-for example, there is much more emphasis on intergroup relations as opposed to economic status and problems of the Negro.-E.M.

\section{BIOGRAPHY}

Tilman, Robert O., ed. International Biographical Directory of Southeast Asia Specialists, 1969. Athens, Ohio: Interuniversity Southeast Asia Committee, Association for Asian Studies, [1969]. 337p. $\$ 4.50$ pa.

Although its purpose-to make known to fellow scholars the background, work, and interests of area specialists-is similar to the Hispanic Foundation's National Directory of Latin Americanists (Suppl. 1DB13), the scope of this new directory is international. Information is based on replies to questionnaires, and includes references to the biographee's five most significant published works and to his current research projects, as well as the expected information on educational background and career. More than half of the 950 Southeast Asia specialists listed are Americans; no completed questionnaires were received from the USSR and the Chinese People's Republic. Indices by nationality, country and field of specialization, and language facility complement the alphabetical arrangement.-E.S.

\section{Genealogy}

Smith, Elsdon Coles. American Surnames. Philadelphia: Chilton, [1969]. 370p. \$9.95. (71-85245).

A book on American surnames must necessarily include names of many national origins. Rather than offer a mere dictionary of names Mr. Smith's method has been to provide a running account of the origin of the most common American family names (and some of their less common variants), with special attention to the social conditions and customs surrounding the adoption of surnames in England and in Europe in general. Names are treated in four main groups: patronymics, occupational names, nicknames, and place names. There is a further section of "Surnames not properly included elsewhere." An index, a bibliography, and an interesting list of the 2,000 most common surnames in the United States complete the volume.-E.S. 


\section{LANGUAGE}

Wall, C. Edward and Przebrenda. Words and Phrases Index. Ann Arbor, Mich.: Pierian Pr., 1969. 390p. \$17.95. (6868874).

Subtitle: A Guide to Antedatings, New Words, New Compounds, New Meanings, and Other Published Scholarship Supplementing the O.E.D., Dictionary of Americanisms, Dictionary of American English, and Other Major Dictionaries of the English Language.

The Words and Phrases Index will be a time-saver for those interested in word usage. It lists unusual words, compound words, and phrases, and provides references to notes or articles in four serial publications where use of the words is discussed. The serials thus indexed are American Notes and Queries (1962-67), American Speech (1925-66), Britannica Book of the Year (1945-67), and Notes and Queries (1925-66). The compilers claim to provide information "often not available in major dictionaries," and include "slang, dialects, non-standard and geographical variations of the English language."-Introduction. The work is a computer product, with words listed alphabetically and phrases listed under the first word other than an article. A second volume will rearrange phrases and compounds under variant entries, and will include entirely new items.-G.L.

\section{LiterATURE}

Hayne, David M., and Tirol, Marcel. Bibliographie critique du roman canadienfrançais, 1837-1900. [Toronto] University of Toronto Pr., [1968]. 144p. \$4.00. (77-406213).

Working within carefully defined limits, the authors have produced a fairly specialized, but very useful work for the student of French-Canadian literature. Nineteenth century works of prose fiction (separately published at least once) by Canadian authors writing in French are the subject of the bibliography. Editions (including serializations and published extracts), English translations, and significant critical studies are cited, together with many helpful notes on publication of the novels and annotations of the critical works. Library locations are indicated for the editions cited. There is an index of authors, titles, and subtitles.-E.S.

Howard-Hill, Trevor Howard. Bibliography of British Literary Bibliographies. Oxford: Clarendon Pr., 1969. 570p. $£ 7,7$ s. (Index to British bibliographies, 1).

First of a projected three-volume series, this compilation "records all publications in English which list the printed works of British writers, which list and describe the works published in Britain from 1475 to the present day, whether generally or classified by period, or literary form or genre, or which describe English works dealing with particular subjects." -Introduction. In general, only bibliographies published since 1890 are considered. A second volume will center on Shakespeare, and the final volume will be a bibliography of British bibliography and textual criticism.

Many forms of material are included: books, periodical articles, auction and exhibition catalogs (but not catalogs of manuscripts and letters, and also excluding theses). The most useful of the six main sections are the final three: Forms and Genres ("Almanacs" to "Unfinished Books"), Subjects ("Accounting" to "Witchcraft"), and Authors (from 1475 to the present, alphabetically arranged), the largest of the sections. The volume has an excellent index; this is essential, for each title is listed only once. The compiler admits that one could argue with his placement of some of the entries, but through the index the user can find all titles pertaining to a topic or an author. Among the arguable placements is the listing of some author bibliographies in the first section entitled "General bibliographies of and guides to British literature." Yet one must be pleased to have such an extensive guide to bibliographies with such liberal cross-referencing.-E.M.

LeSage, Laurent and Yon, André. Dictionnaire des critiques littéraires; guide de la critique française $d u X X^{e}$ siècle. 
University Park: Pennsylvania State University Pr., [1969]. 218p. \$6.50. (688181).

This work is a biographical dictionary as well as a concise introduction to modern French literary criticism. A biographical sketch is given for each of the 119 critics listed; the critic's esthetic theory and approach to literature, his concepts and criteria-his méthode-are discussed briefly. A list of the author's major writings concludes each summary. Selection of entries was based on the critic's professional reputation and prominence. The work's detailed introduction outlines the development of French literary criticism and its function in the nineteenth and twentieth centuries. A "bibliographie générale" lists suggested further reading on the theory of literary criticism, thus supplementing the historical survey. The volume should serve as a valuable guide for the beginning student of the subject.-H.P.

Moisés, Massaud. Bibliografia da literatura portuguêsa. São Paulo; Editôra da Universidade de São Paulo, 1968. 383p. (68-3479).

With the collaboration of a small group of fellow scholars, Professor Moisés has produced a basic bibliography of Portuguese literature from the time of the Troubadours to the modern period. Following a section of general works the arrangement is by literary period, with subsections for literary genres, often including such related areas as religion, philosophy, historiography, and the literature of travel. Listings for individual authors include both editions of their works and critical studies (in periodical as well as book form). There is a detailed table of contents, but the index is of authors of the critical studies only.-E.S.

Velz, John William. Shakespeare and the Classical Tradition; a Critical Guide to Commentary, 1660-1960. Minneapolis: Univ. of Minnesota Pr., [1968]. 459p. \$17.50. (67-14377).

"For three centuries, Shakespeare studies have been touched ... . by the question of Shakespeare's participation in the clas- sical tradition. This bibliographical guide is an attempt to gather, classify, summarize, and appraise the commentary which has been written since 1660."-Preface. The editor of this selective and critical guide emphasizes the inclusion of recent research material, a high percentage of the items having been written since 1940 . It is stressed that "all relevant criticism and scholarship in English, French, and German" is included. Following a list of bibliographies consulted and a listing of general works treating the influence of classicism on Shakespeare, the work's main section cites the specific studies of Shakespeare's classicism in a generic classification (Comedies, Histories, etc.). For each entry a summary of content and a critical appraisal of interpretation and method is given. Careful attention has been given to bibliographical detail, and the extensive index takes into consideration all aspects of the reader's approach to the bibliography.-H.P.

\section{Motion Pictures}

Sarris, Andrew. The American Cinema: Directors and Directions, 1929-1968. New York: Dutton, 1968. 383p. \$7.95. (6912602).

Michael, Paul, ed. The American Movies Reference Book: the Sound Era. Englewood Cliffs, N.J.: Prentice-Hall, 1969. 629p. ill. \$29.95. (68-13401).

Having declared that "there is no such thing as an objective film history," Andrew Sarris sets forth his own singularly subjective views of cinema and its directors in the United States since 1929. His is a classified approach, beginning with "Pantheon Directors . . . who have transcended their technical problems with a personal vision of the world" and including such categories as "Strained Seriousness ... . talented but uneven directors with the mortal sin of pretentiousness." From an objective standpoint, Mr. Sarris is quite well qualified to pronounce on these matters, having been a film critic for various journals and a professor of cinema at a major university. And, if one is willing to accept his judgment, the book can be a valuable tool for evaluating the total artistic merit 
of a particular director. Its reference use, however, will probably be restricted to the extensive directorial chronology - a list of directors and productions representing a "weighted critical valuation"-and to the "Directorial Index to the American Cinema," a title listing of major Englishlanguage films since 1929.

In contrast to Sarris' approach, Paul Michael's volume provides very little critical evaluation or judgment in depth. Of course, the mere decisions of inclusion and exclusion imply judgment, but this work is much more inclusive and of quite different purpose from Sarris' book. Its first chapter offers an overview in which major developments in American film history are outlined in brief. Next comes an alphabetical list of six hundred film stars selected on the basis of quality, contemporary prominence and length of career, and attempting a cross section of various types of performers. Whereas Sarris treats major foreign directors who have made English-language films, Michael does not include foreign stars "unless their success was due in substantial part to their exposure in American films." The biographical data includes only verifiable facts (birth date, marriages and divorces, children, and a list of feature films in which the actor appeared), a prudent limitation in dealing with the lives of movie stars.

Chapter three lists slightly more than a thousand films, selected on the basis of awards and box office receipts; complete casts and major production facts are included. Further sections list over a hundred directors and producers, with their works cited chronologically; and the final chapter deals with the various awards granted by the movie industry. The index lists names of actors, directors, and producers in separate alphabets. Despite certain limitations, this profusely illustrated work is as fascinating as the history of American movie-making itself and, indeed, reminds one of nothing so much as a Cecil B. DeMille extravaganza with a cast of thousands.-G.L.

\section{ANTHROPOLOGY}

Australian National University. Dept. of Anthropology and Sociology. An Ethno- graphic Bibliography of New Guinea. Canberra: Australian National University Pr., 1968. 3v. $\$ 12.00$ (Aus) pa. (6813734).

Contents: v.1, Preface; Bibliographies and reference works; Author index; v.2, District index; v.3, Proper names index.

Intended as "an aid to research on the traditional and changing indigenous cultures of New Guinea" (Preface), this bibliography attempts completeness in the areas of material culture and social organization, and is selective in related subjects. Books, articles, and contributions to collections covering more than a century (with 1964 as closing date) are listed alphabetically by author, with full bibliographic details. Unsigned articles appear under journal title. All items are drawn together by administrative districts (as of 1960) in the District Index, and by names of physical features, language, and social groups in the Proper Names Index. In both these indexes reference is to the full citation in the Author Index. No list of journals appears, but spot checking turned up only one group of entries in which a journal was cited in unexplained abbreviated form. Supplements are planned.-R.K.

\section{Political Science}

Bollens, John Constantinus; Bayes, John R.; and Utter, Kathryn L. American County Government, with an Annotated Bibliography. Beverly Hills, Calif.: Sage Publications, [1969]. 433p. \$15.00. (6920118).

Bollens and his associates aim in this work to survey "the current state of knowledge about counties" and to suggest "research in this field that seemingly would be highly productive."-Preface. Part I, in essay form, is a general analysis of the literature and research needs. Part II is concerned with new approaches in county research and includes a discussion of selected findings. Most important from the reference point of view is Part III, "A Bibliographical Commentary." This constitutes the bulk of the book and is organized under seven major headings (e.g., finance, organization, politics). Within each sec- 
tion general materials are followed by a discussion of publications relating to county government in the individual states. There is an author index.-M.M.

\section{Craig, Frederick Walter Scott. British} Parliamentary Election Statistics, 19181968. Glasgow: Political Reference Publications, 1968. 110p. 70s. (68-57148).

Kinnear, Michael. The British Voter; an Atlas and Survey since 1885. Ithaca: Cornell University Pr., 1968. 158p. \$12.50. (68-9750).

In the preface to British Parliamentary Election Results, 1950-1964 (Cambridge, 1966), Professor David Butler comments on the need for carrying statistical tables of elections back to 1918 or to 1885 . With the appearance of these two new volumes the need is met and they, together with Butler's work and British Political Facts, 1900-1967 (Guide CI125), provide the student with a large body of raw data.

The Craig compilation aims to provide "an authoritative and continuing reference to British election statistics since 1918."Preface. Taking most of the material from his forthcoming book, British Parliamentary Elections: Constituency Results, the author provides a series of tables giving the total votes for the various parties, percentage breakdown for general elections and by-elections, the politics of constituencies, gains and losses, cost of elections, and other statistics relating to British elections of 1918 to 1968. No attempt has been made to draw conclusions or to explain the results of the elections. A second edition is planned for publication after the next general election.

Kinnear's volume "examines the social, economic, and organization background of British politics on a nationwide scale, over the period since 1885."-Introduction. This is done by means of tables, commentary, and maps of land areas. Professor Kinnear devotes a large part of his work to the confusion of the elections of the $1920 \mathrm{~s}$, as this period saw the establishment of two major parties and the transition to the new period of strong political alignments. The maps show the political decisions of each election district and the large metropolitan areas. They are so detailed as to require careful study, and one could wish for an overlay map of British counties; possibly the use of color instead of shading would have made for easier reading.

The two volumes complement each other: for example, The British Voter does not include by-elections while it does provide description and commentary. Unfortunately the statistics of the two works do not agree even upon the total vote in some of the elections, although in most cases the differences are slight. Each volume concludes with a select bibliography. - E.M.

\section{INTERNATIONAL ORgaNIZATIONS}

Yearbook of International Congress Proceedings. Ed. 1- . Brussels: Union of International Associations, 1969-

Contents: v.1, Bibliography of reports arising out of meetings held by international organizations during the years 196067. Eyvind S. Tew, ed. 640p. \$20.00.

The main purposes of this yearbook, intended as a companion to the Yearbook of International Organizations (Guide CJ 143), are to draw attention to the existence of the reports of international congresses and to indicate how they may be obtained. All types of proceedings, minutes, preprints, working papers, etc., are included, whether issued separately or incorporated in periodicals, provided that they are more than about ten pages in length and are concerned with the substantive, as opposed to the purely administrative, interests of the organization. Publications of the United Nations and its major specialized agencies are not covered, but a supplementary section indicates what catalogs and indexes are available for these and from whom they can be ordered. Arrangement is chronological according to date of meeting. Three indexes provide easy access to full bibliographic information: Index of Organizations (with listing by English title), Author/Editor Index, and Subject Keyword Index. This first edition was preceded by the Union's Bibliography of Proceedings of International Meetings, the three vol- 
umes of which covered meetings held in 1957, 1958, and 1959.-N.S.

\section{Maps and AtLases}

Poland. Wojsko Polskie. Sluzba Topograficzna. Pergamon World Atlas. Oxford and New York: Pergamon Pr., 1968. 525p. 42cm. \$59.50. Map 67-8.

Not an entirely new work, this is rather an English edition, updated and augmented, of the Atlas Swiata which was prepared by the Polish Army Topographical Service and originally published 1962 65. Political maps now represent the world as of January 1, 1967, and additional maps for the United Kingdom and Canada have been included. Most significant, perhaps, is "the exceptionally large-scale and detailed mapping of Eastern Europe, the USSR, and the Far East, based on sources not readily available to any publisher in the West."-Preface. There are some two hundred pages of geographical maps (a high percentage of them on foldout pages which allow presentation of relatively large-scale maps while avoiding the problems presented by centerfold layouts), and dozens of thematic and special topic maps. The index includes about 140,000 names.-E.S.

Rand McNally \& Co. The International Atlas. Chicago: Rand McNally, [1969]. 280, 223p. $37 \mathrm{~cm}$. \$35.00. (77-78100).

Title and introductory and explanatory matter also in German, Spanish, and French.

Balanced coverage and multilingual explanatory matter play an important part in giving international emphasis to this new atlas. The amount of space allotted to each region is meant to reflect "its relative economic and cultural signficance on the world scene, as well as its total population and area," and the "planning of individual map layouts is from the point of view of geographic and economic regions" (Foreword) rather than that of the boundaries of individual nations. Local forms of names have been used as far as possible, with English forms employed for major water bodies, mountain ranges, and features extending beyond na- tional borders. There are sections for world, ocean, and continent maps, for regional maps, and for metropolitan area maps, the latter being grouped for convenience of comparison and to avoid the use of insets in the regional maps. An index of 170,000 names gives latitude and longitude as well as page reference. Maps are generally more attractive than those in the publisher's earlier, well-known atlases. The frequent occurrence of doublepage spreads raises the usual question about the practicability of rebinding the volume.-E.S.

Wheat, James Clements, and Brun, Christian F. Maps and Charts Published in America before 1800; a Bibliography. New Haven: Yale University Pr., 1969. 215p. \$30.00. (69-15464).

Carefully edited and handsomely produced, this is the first bibliography "which attempts to describe the entire known cartographical contribution of the American press prior to 1800 ."-Preface. Not only separately published maps and charts are listed, but also those published in books, pamphlets, almanacs, and magazines, and even some maps known to have been published but of which no copies are believed extant. Maps are grouped by geographical and political areas, then chronologically. Full descriptions are provided, together with bibliographical references and locations of copies. Like Ena Yonge's Catalogue of Early Globes . . . Conserved in the United States (New York, 1968), which it complements in part, this is an interesting and useful work for the cartographer and the historian.-E.S.

\section{History}

Mullins, Edward Lindsay Carson. A Guide to the Historical and Archaelogical Publications of Societies in England and Wales, 1901-1933. London: Athlone Pr., 1968. 850p. \&10,10s. (79-367032).

This guide is intended as a complement to Writings on British History, 1901-1933 (London, 1968- ), which omits publications of historical societies, and its listings are continued in Writings on British History, 1934- (Guide DC125), which includes society materials. The organizations, which 
number over 400 , are arranged alphabetically; after a brief indication of area of interest, there follows a list of each society's publications. Included for every serial title is a complete record of its contents. The bibliography is extensively indexed, by subject and by author, and should prove a useful tool for dealing with a rather elusive body of literature important for historical and archaeological research.-N.S.

Rouse, Richard H. Serial Bibliographies for Medieval Studies. Berkeley: University of California Pr., 1969. 150p. \$5.00. (68-31637).

An annotated list of nearly 300 serial bibliographies on the various aspects of medieval studies, this book will be of great use to reference librarians and medieval scholars. In addition to the obvious serial bibliographies in this field, the editor has included bibliographic essays, collections of select tables of contents, and accessions lists of special libraries; he has excluded only national bibliographies, standard periodical indexes, and serial guides to dissertations. For the purpose of this work the Middle Ages is defined as "the centuries which fall between the emergence of Christianity and the voyages of exploration." - Introduction. Thus, there is the inevitable and useful overlap into classical studies and the Renaissance. Geographically, in addition to Europe, the guide includes works on or from areas with which medieval Europe came into contact-Iceland, North America, the Middle East, Byzantium, and Asia.

Arrangement of the book is good: the first section is comprised of general, regional, and cultural bibliographies; the second is of subject bibliographies, with eight subdivisions, from "Archival studies" to "Science, technology, and medicine." There is a title index and an index of editors.G.L.

Snow, Philip A. A Bibliography of Fiii, Tonga, and Rotuma. Preliminary working ed. Coral Gables, Fla.: University of Miami Pr., 1969. 418p. $\$ 13.50$ pa. (6916193).

Although designated as a preliminary edition, the sheer bulk of its listingsmore than 10,000 items-suggests that this version may remain a standard tool for Pacific studies for years to come. The bibliography aims at comprehensive coverage of published material (in books, periodicals, and selected British newspapers) regardless of prospective worth to the researcher. Government reports have been included, as have vernacular literature and reviews of books about the regions; only occasional citations are given to manuscript materials. A classified arrangement is employed within four main sections: a combined section headed "Fiji, Tonga, Rotuma" cites works dealing at some length with more than one of the territories, and this is followed by separate sections for each territory. The Fiji section is, understandably, the largest, with nearly 6,600 entries; the combined section runs to slightly more than 1,900 , Tonga to about 1,350, and Rotuma to just under 200 entries. There is an author index.E.S.

Wood, Eric S. Collins Field Guide to Archaeology. [2d rev. ed.] London: Collins, [1968]. 384p. ill. 30s. (68-119612).

Well organized and readable, this handbook concerns "the visible remains of man's occupation of Britain from the earliest times to almost the present day" (Preface) and presents a great deal of information for the amateur. Part I, "General Background," summarizes history, climate, and successive cultures of Britain. Part II, the major portion of the text, is entitled "Field Antiquities" and is a description of remains arranged by type (e.g., settlements, roads, military works), with many examples cited. Part III is a short account of the "Technical and Legal Aspects of Archaeology," and Part IV, "Aids and Suggestions," lists sites to visit, further sources of information, and a long, up-to-date bibliography. Regional maps, indexes of places and subjects, a glossary, and instructions for use of the guide are all helpful features. Excellent photographs scattered throughout are, unfortunately, rarely set in conjunction with related text.-R.K. 